\title{
MEMORIAL TO STEPHEN D. KERTESZ
}

Constancy was the hallmark of Stephen Kertesz's life and work. That seems a quality more often achieved in the breach in the modern age. Too often, pride, self-interest and a ceaseless drive for power and success thwart pure intentions. In my experience, survival and self-preservation, always "in a good cause," oftentimes demand tradeoffs if not abandonment of principles and friends when expediency beckons. Even the noblest and most saintly are weak. Yet so far as I could tell, Stephen Kertesz was an exception, one of the very few.

First, he was utterly constant in his devotion to scholarship from beginning to end. He proved his scholarship as a Rockefeller Foundation Fellow. At the end, from October, 1984 to late 1985, he published three landmark works. They were Between Russia and the West, Diplomacy and Values and The Last European Peace Conference. Of the first, General Andrew J. Goodpaster could write "Seen through the eyes of a deeply-involved senior diplomat . . . it tells a poignant and graphic story of the ordeal in Hungary through the war, the attempted armistice and ensuing German seizure of power, the Soviet occupation, and finally the subsequent years of Soviet domination." Professor Robert H. Ferrell of Indiana University who knew Kertesz's scholarship well declared: "Kertesz writes evocatively, imaginatively with verve, of the very human Hungarian problems." I found that "This book lights up dark corners of contemporary history that had not been illuminated before." Stephen was proud that his own beloved University of Notre Dame Press published this book in an elegant and attractive format. In his era as chairman of the Committee of International Relations the Press had attained heights in international relations publishing seldom realized by a university or commercial press. He must have known this book was his valedictory with the Press. In it as in his other writings, he held to canons of scholarship shunning every successive fad and fashion whatever the inducements to do otherwise.

Diplomacy and Values rehearsed well-known and not so wellknown chapters of his life in Europe and America. The text was partly the critique of friends but throughout the words and deeds were his. His colleagues came together to pay tribute to him as 
diplomat and scholar, to his views on diplomacy and great power politics, and to his knowledge of diplomacy and the nuclear threat. Jack Kennedy was the driving force in coping with plans and logistics. Bob Fitzsimons captured nuances of Kertesz's intellectual and personal journey that all of us felt but none articulated so poignantly: "unfailingly courteous," "the inclination to be positive," "remarkably open to ideas and suggestions," "the Christian as diplomat," "his unusual combination of realism and unremitting aspiration," and "his good example" better even than "his wise counsel." When those two steadfast friends had once spoken of weariness and age lessening hours of reading, Kertesz had replied: "One can always think." Again constancy.

That thinking and searching and reaching out continued to the end. When I called him two days before his death, so accustomed had we become to thinking aloud that I talked about heart attacks sometimes lengthening persons' lives as they necessarily grew more careful about their health. His weakened voice should have told me the end was near. But even if had I known, I suspect I would have sought some engagement of minds. He had after all addressed so many of my problems and those of other close friends. It seemed in his last years, he could not allow a Saturday to pass without phoning to talk about a book, a young scholar, a minority fellow, projected travel or some deep concern much closer to home. In the constancy of his friendship, Stephen had no equal in high or low places.

When he arrived at Notre Dame, an exiled diplomat, certain colleagues wondered if he "would in effect be a time-server, a colleague but never an ally in the day and night battles about education." They misread the constancy of his resolve as did the staff at the Rockefeller Foundation who questioned support to the Committee on International Relations. Sixty books later, all had to recognize that here was a leader as firm in his commitments as was the tradition his University embraced.

I have been cited as the source of a phrase describing him as "a broker in ideas and talents" and as a leader this was one of his strengths. But more important, he was free of all envy, jealousy and bitterness and persons of every ideological persuasion knew it. Because he was fair-minded and even-handed he could enlist speakers of widely divergent viewpoints. He could not rest until he had put things right in organizing a conference, balancing legitimate outlooks, correcting a Latin phrase, summarizing an 
agreement or treaty, checking a fact or date or supporting a friend in need. What most of us pledged to do for others and conveniently forgot, Stephen carried out in full measure.

Young and old search for examples or models to inspire their lives and oftentimes are disappointed. Stephen Kertesz did not disappoint us. He was an example for scholars when in his final book, The Last European Peace Conference, he made available hitherto unpublished sources from the Paris Conference in 1946 and laid bare the early conflicts between the Soviets, Eastern Europe and the United States which none of the negotiators could resolve. $\mathrm{He}$ was an example of energy and imagination for those who later directed public affairs programs. He was an example in putting the search for truth above all selfish considerations. He inspired those who would rest on their oars with his intellectual curiosity and high standards of responsibility and excellence. But most of all, he taught what it was to be a friend, everlastingly faithful, trusting, understanding and compassionate. It is safe to prophesy that in all these respects, we shall not see his like again in our day.

- Kenneth W. Thompson 